FACTA UNIVERSITATIS

Series: Working and Living Environmental Protection Vol. 18, № 2, 2021, pp. 103 - 111

https://doi.org/10.22190/FUWLEP2102103M

Original Scientific Paper

\title{
IMPACT OF ENERGY EFFICIENCY OF MODERN RESIDENTIAL AREA ON THE ENVIRONMENT
}

\author{
UDC 620.9:697
}

\section{Milena Mančić1, Miomir Raos ${ }^{1}$, Marko Mančićé, Milan Protić1, Milena Medenica ${ }^{1}$, Milena Rajić ${ }^{2}$}

${ }^{1}$ Faculty of Occupational Safety, University of Niš

${ }^{2}$ Faculty of Mechanical Engineering, University of Niš

\begin{abstract}
Improving the energy efficiency of facilities should reduce greenhouse gas $(G H G)$ emissions and independence from energy imports, increase jobs and energy security, as well as encourage researchers in further research to be creative, innovative and competitive. With about $40 \%$ of primary energy consumption accompanied by $36 \%$ of greenhouse gas emissions, the construction sector is one of the largest consumers in Europe. Energy consumption of the construction sector in Serbia has a significant share in total energy consumption of $48 \%$, $65 \%$ of which refers to energy consumption in residential buildings. The legislation on Energy efficiency in Serbia implies a specific energy consumption of $65\left[\mathrm{kWh} / \mathrm{m}^{2}\right]$ for one apartment buildings and $60\left[\mathrm{kh} / \mathrm{m}^{2}\right]$ for multi-apartment buildings. In this paper, a settlement with 50 apartment buildings is analyzed, impact on building envelope construction and applied heating system type to carbon and primary energy footprint is estimated using the degree-day method. Although the mentioned specific energy consumption limit is determined by national legislation, this paper tackles the benefits and costs of reducing energy and carbon footprint by reducing carbon and primary energy footprint to a value lower than the mentioned limit.
\end{abstract}

Key words: energy efficiency, carbon footprint, housing

\section{INTRODUCTION}

Energy efficiency in buildings is recognized as one of the priorities of the Energy Union Strategy [1]. Improving the energy efficiency of facilities should reduce greenhouse gas (GHG) emissions and independence from energy imports, increase jobs and energy security, as well as encourage researchers in further research to be creative, innovative and competitive. The construction sector, with a consumption of about $40 \%$ of primary energy and $36 \%$ of

Received November 29, 2020 / Accepted April 21, 2021

Corresponding author: Milena Mančić

University of Niš, Faculty of Occupational Safety, Čarnojevića 10a, 18000 Niš, Serbia

E-mail: milena.mancic@znrfak.ni.ac.rs 
greenhouse gas emissions, is one of the largest consumers in Europe [2]. In particular, the housing sector consumes more than a quarter of the total energy and more than two-thirds of the entire construction sector, which is shown in Figure 1. The European Union has created a legal framework for reducing energy consumption and achieving certain savings in buildings. The Energy Efficiency Directive (EED) and the Renewable Energy Directive (RED) contain important measures, but the biggest step forward has been made through the Building Energy Performance Directive [3]. This Directive sets as one of the goals that from 2018, facilities will be built so that they almost meet the requirements of net-zero consumption facilities (NZEB) [1]. Net-zero consumption facilities are defined as facilities with very high energy efficiency, where energy needs are mostly met from renewable energy sources. The factor that appears as a novelty is the justification of the investment versus savings and the optimal investment costs. Optimal cost levels represent the energy performance that leads to the lowest possible costs over the life of the building [6]. [1-6]

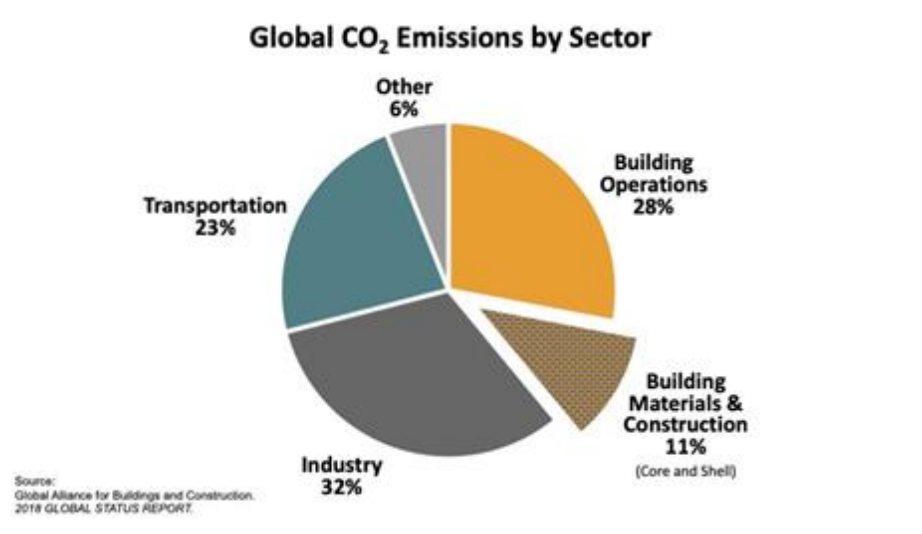

Fig. $1 \mathrm{CO}_{2}$ emissions from different sectors expressed in [\%], in the European Union [7]

Energy consumption in the housing sector in Serbia has a significant share in total energy consumption of $48 \%$, of which $65 \%$ refers to energy consumption in individual housing. The application for membership in the European Union raises the question of meeting European goals in terms of energy efficiency, renewable energy and reduced $\mathrm{CO}_{2}$ emissions. As a member of the Energy Community of the European Union, Serbia has committed itself to gradually implementing chapters relevant to energy from European legislation in order to meet the requirements related to energy consumption in buildings. Serbia has already created a legal framework for that by introducing the Law on Efficient Use of Energy and the Action Plan for Energy Efficiency. Improving energy efficiency can bring a whole range of positive effects to the economy and society. Energy efficiency programs are often assessed only on the basis of energy savings achieved, which contributes to a significant underestimation of the overall value of improvements in the field of energy efficiency. Improvements in energy efficiency can produce significant positive macroeconomic effects such as increasing jobs, reducing electricity import needs and gaining energy independence as well as energy security. 
Legislation on energy efficiency in Serbia implies a specific energy consumption of $65\left[\mathrm{kWh} / \mathrm{m}^{2}\right]$ for a residential building with one apartment and $60\left[\mathrm{kWh} / \mathrm{m}^{2}\right]$ residential buildings with multi-apartment units. Statistics show that about 70 [\%] of the population in Serbia live in individual housing, which participates with more than 50 [\%] in total electricity consumption and $32[\%]$ in final energy consumption.

This paper discusses the share of energy consumption of an individual residential building in Serbia, as well as the impact of building envelope construction on carbon dioxide emissions and primary energy consumption. On that occasion, a settlement with 50 individual residential buildings was analyzed.

\section{METHODOLOGY}

The influence of the construction of the building envelope and the applied heating system on the carbon dioxide emission and the primary energy consumed is estimated by many degree-day methods. Although the national legislation determines mentioned limit of specific energy consumption, this paper deals with the analysis of the impact of the construction of facilities and applied thermodynamic systems on costs and benefits by further reducing the specific consumption to levels below the prescribed values.

The choice of appropriate technologies in residential buildings is often a challenge in the design phase, especially since many different criteria are considered. The decision is often made based on one criterion, which is usually energy savings.

The paper discusses a modern residential area with 50 identical individual residential buildings, shown in Figure 2.

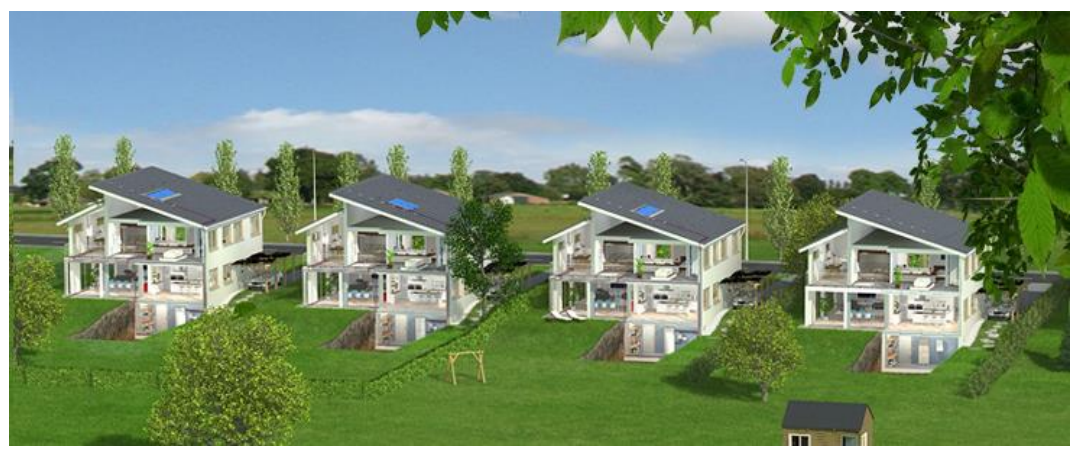

Fig. 2 A series of identical objects with modern design

The impact of the building envelope construction and the applied heating system on the final energy consumption is estimated by applying the degree-day method. The number of degree days is a key parameter in estimating the annual energy consumption for heating by the degree-day method. In the domestic practice so far, the number of degree-days was determined on the basis of average monthly temperatures. Using the mean daily outside air temperatures makes it possible to apply different criteria for calculating SD. Using six different criteria, the degree-day values for four distinct heating seasons in Belgrade were calculated. The influence of heating limit temperature and internal temperature on the number of degree-days was analyzed. [9] 
$\mathrm{CO}_{2}$ emissions and primary energy consumption are recalculated on the basis of the calculated required amount of energy for heating, with the application of conversion factors.

The usual type of thermal envelope construction of single-family individual residential buildings in Serbia involves the use of solid brick or hollow brick, cement mortar and thermal insulation layer of expanded polystyrene (XPS) and "fert" mezzanine construction.

The location of this settlement has not been considered in detail, the city of Nis and its surroundings have been taken to make models.

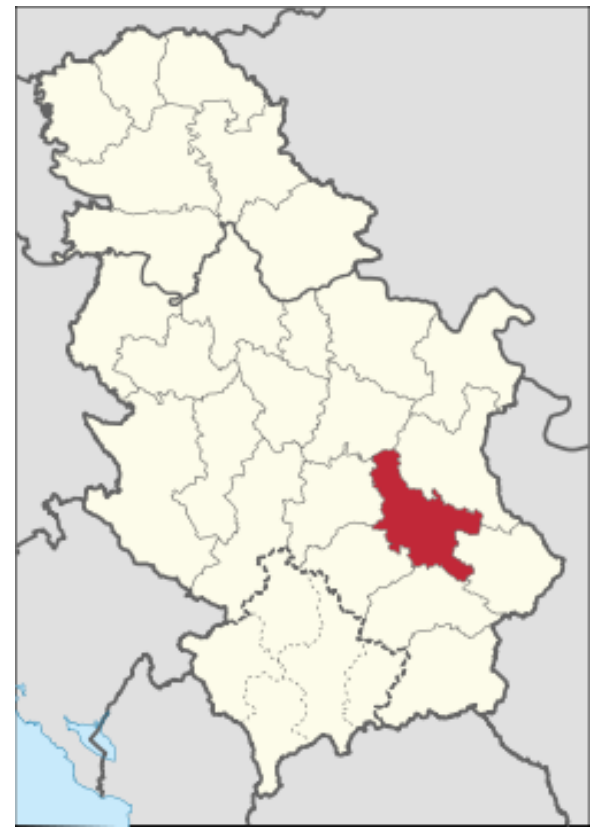

Fig. 3 Macro location of the city of Nis

Table 1 Overview of project conditions for the city of Nis

\begin{tabular}{lc}
\hline External projected temperature for heating & $-14.5\left[{ }^{\circ} \mathrm{C}\right]$ \\
Internal projected temperature & $20\left[{ }^{\circ} \mathrm{C}\right]$ \\
Average external temperature in the heating period & $5.4\left[{ }^{\circ} \mathrm{C}\right]$ \\
Projected external temperature for diffusion & $-5\left[{ }^{\circ} \mathrm{C}\right]$ \\
Number of heating degree days HDD & 2613 \\
Number of heating days HD & 179 \\
Number of humidification days & 60 \\
Number of dehumidification days & 90 \\
\hline
\end{tabular}

For the purposes of the research, it is taken that these are individual residential buildings with natural ventilation, the position of these buildings can be considered open (number of facades exposed to wind>1), for the type of construction it is taken that it is a difficult type of construction. Residential heating is provided $24 \mathrm{~h}$ a day, 7 days a week, All facilities located in this particular village are taken to have: 
- useful floor heating surface: $164,4 \mathrm{~m}^{2}$

- an envelope surface of individual residential building: $408,58 \mathrm{~m}^{2}$

- Volume of ventilated/heated space: $443.82 \mathrm{~m}^{3}$

- Shape factor: Fo $=0.95[\mathrm{~m}-1]$

- Type of building: new building.

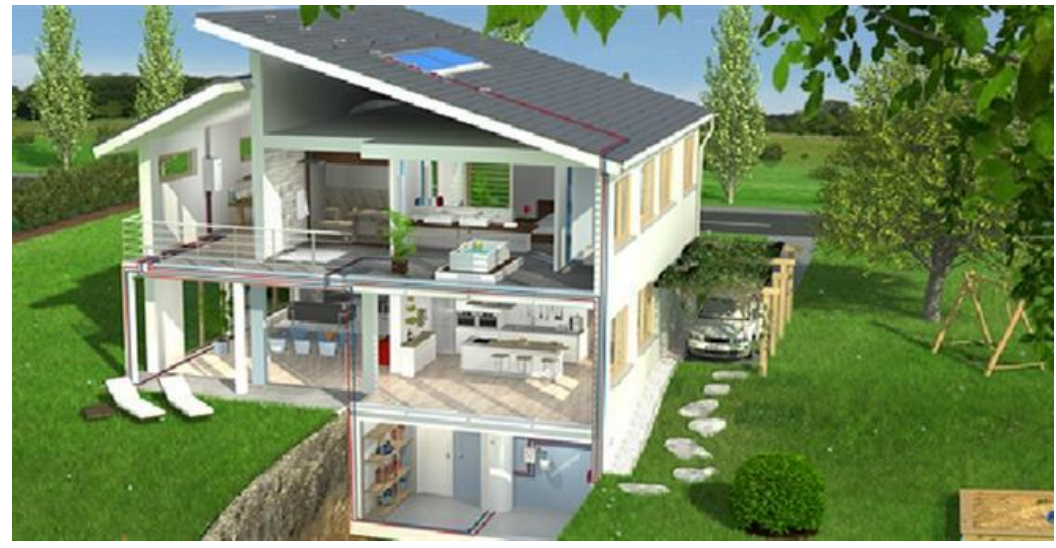

Fig. 4 Representation of the architecture of one of the settlements of 50 such buildings considered in the paper

Table 2 shows the segments of the position outer walls in relation to the orientation towards the side of the world and shows the uniformity of the surface towards all sides of the world, so that there is no dominant orientation, while the largest area is transparent partitions on the south facade (Table 3).

Table 2 The position of the segments of the outer walls in relation to the orientation towards the sides of the world

\begin{tabular}{lc}
\hline & Surface $\left[\mathrm{m}^{2}\right]$ \\
\hline To North & 33,08 \\
To East & 31,06 \\
To South & 29,38 \\
To West & 30,154 \\
\hline
\end{tabular}

Table 3 The position of the segments of transparent partitions in relation to the orientation towards the sides of the world

\begin{tabular}{lc}
\hline & Surface $\left[\mathrm{m}^{2}\right]$ \\
\hline To North & 4,32 \\
To East & 2,46 \\
To South & 10,64 \\
To West & 3,66 \\
\hline
\end{tabular}


Table 4 Overview of the heat transfer coefficient through the thermal envelope of the building

\begin{tabular}{lccc}
\hline Position & Label & $\mathrm{U}\left[\mathrm{W} /\left(\mathrm{m}^{2} \mathrm{~K}\right)\right]$ & $\mathrm{U}_{\max }\left[\mathrm{W} /\left(\mathrm{m}^{2} \mathrm{~K}\right)\right]$ \\
\hline Outer wall & $\mathrm{SZ1}$ & 0.217 & 0.3 \\
Windows and balcony doors & PR1 & 1 & 1.5 \\
Exterior door & VU & 1.5 & 1.6 \\
Mezzanine construction under unheated space & TAV & 0.175 & 0.3 \\
Floor on the ground & POD & 0.126 & 0.3 \\
\hline
\end{tabular}

The maximum values of the heat transfer coefficients shown in Table 4 correspond to the values for the new buildings of the Energy Efficiency Ordinance.
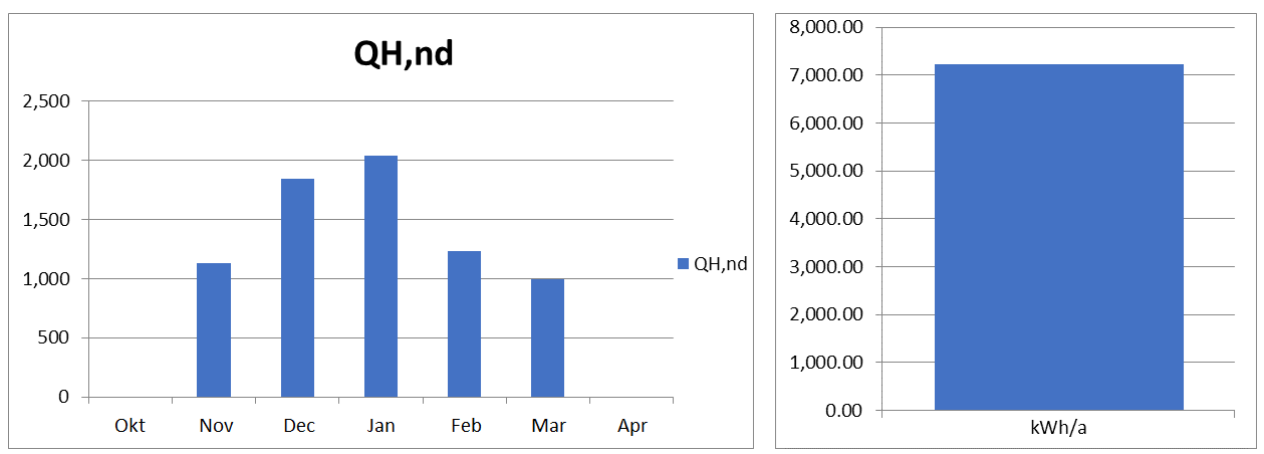

Fig. 5 Diagram of the required heat for heating by months

Figure 5 shows the required amount of heat for heating QH and for a building that is insulated with XPS $15[\mathrm{~cm}]$ and whose transparent partitions (construction joinery) are PVC five-chamber windows with low-emission three-layer glass package $4+8+4+8+$ 4 (unit) with argon, whose maximum heat transfer coefficient is $1.3\left[\mathrm{~W} / \mathrm{m}^{2} \mathrm{~K}\right]$. The shown required amount of heat occurs in the autumn-winter period, and the expected maximum is in the coldest months of December and January. For this type of facility, the total required amount of heat for heating for the whole year is slightly above 7100 [kWh].

Figure 6 presents a graphical representation of the final energy consumption analysis of a modern 50 house settlement with a variation in the thickness of the thermal insulation sheath (XPS) from $12[\mathrm{~cm}]$ to $22[\mathrm{~cm}]$, (starting from 12, 15, 18, 20, $22[\mathrm{~cm}]$ ) and construction joinery whose the heat transfer coefficient is $\mathrm{U}_{1}=1.3\left[\mathrm{~W} / \mathrm{m}^{2} \mathrm{~K}\right]$, where the thickness of the thermal insulation of the ceiling also varies $(16,18,20,22,25,30[\mathrm{~cm}])$. We notice that the final energy consumption will be equally affected by the thickness of the thermal insulation layer of the building envelope and the thickness of the thermal insulation layer of the attic. However, the justification of the financial investment will depend on the expected savings.

Figure 6 gives a graphical representation of the dependence of energy consumption for heating $[\mathrm{kWh}]$ for the entire settlement made of 50 identical buildings and in the upper paragraph of the parameters listed. We get the greatest savings if we place the largest thickness of thermal insulation material, both on the outer casing and the attic structure, but the histogram shows that the largest drop in heating energy consumption when installing insulation of $18 \mathrm{~cm}$ for the casing and $20 \mathrm{~cm}$ on the attic structure. 


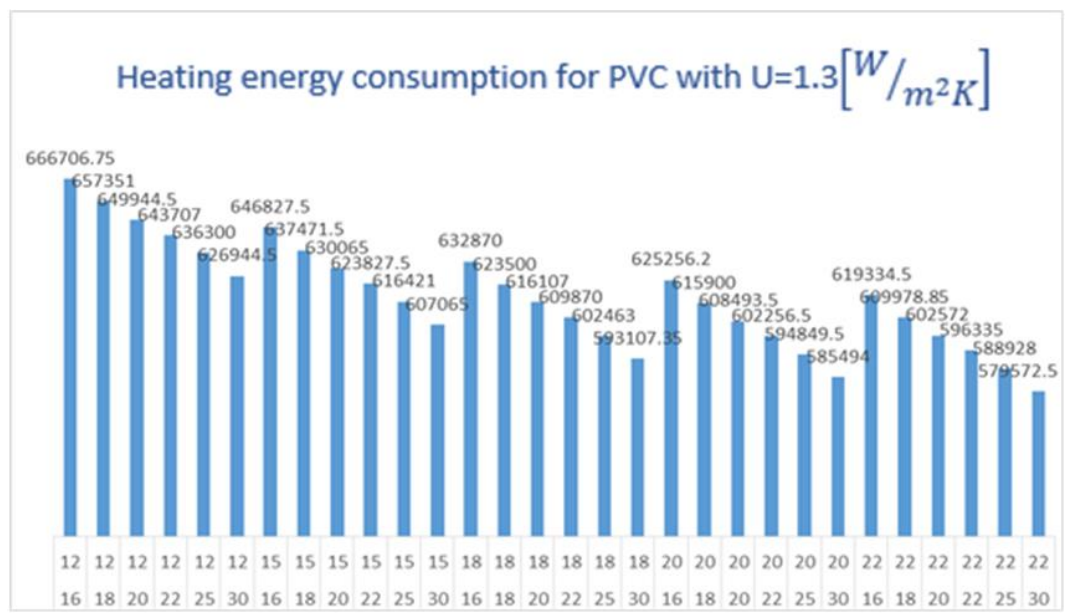

Fig. 6 Histogram of energy consumption for heating a building depending on the analyzed parameters

Figure 7 shows the energy consumption for heating the entire settlement $[\mathrm{kWh}]$ if the choice of construction joinery is chosen one whose heat transfer coefficient is 0.96 $\left[\mathrm{W} / \mathrm{m}^{2} \mathrm{~K}\right]$, and the application of different thicknesses of insulation material both the outer shell and ceiling constructions. What we notice in Figure 7 is that the biggest drop in consumption is again when the insulation of the outer casing of $18 \mathrm{~cm}$ and the insulation thickness of the ceiling structure of $20 \mathrm{~cm}$ is installed, after these insulation thicknesses, the trend of decreasing consumption exists but is much smaller.

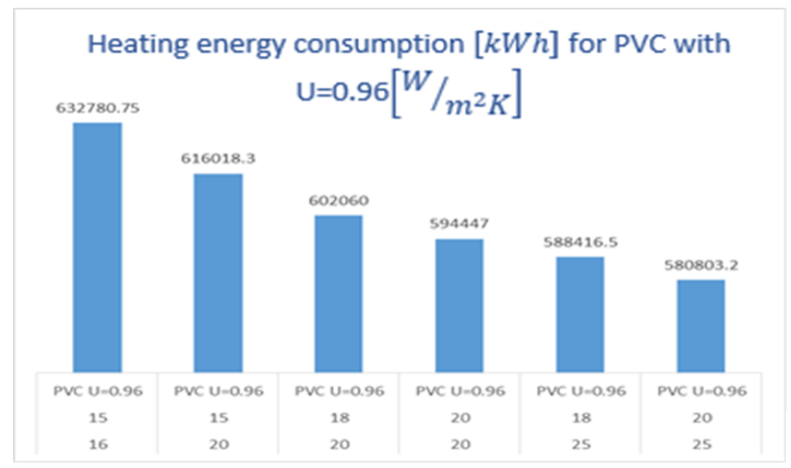

Fig. 7 Histogram of energy consumption for heating a building depending on the analyzed parameters

Figure 8 shows the analysis of primary energy consumption and $\mathrm{CO}_{2}$ emissions of a modern settlement with a variation in the thickness of the thermal insulation sheath from $12 \mathrm{~cm}$ to $22 \mathrm{~cm}$ and construction joinery $\left(\mathrm{U}_{1}=1.3 \mathrm{~W} / \mathrm{m}^{2} \mathrm{~K}\right.$ and $\left.\mathrm{U}_{2}=0.96 \mathrm{~W} / \mathrm{m}^{2} \mathrm{~K}\right)$, taking into account different insulation thicknesses ceiling constructions (from 16-30 [cm]) and various heating systems. 


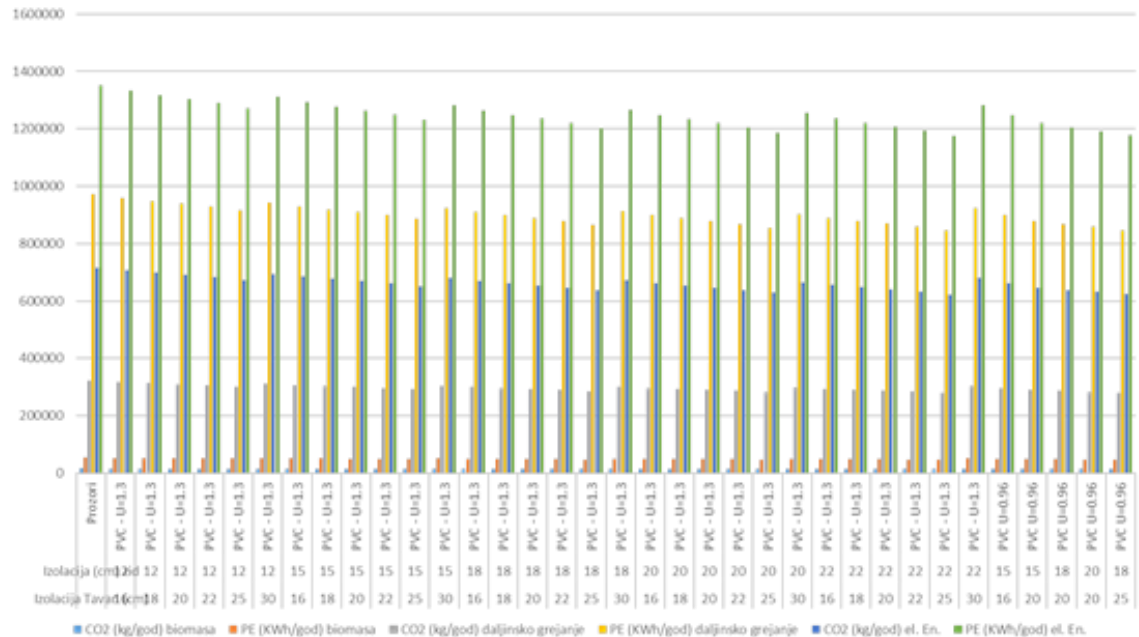

Fig. 8 Analysis of primary energy consumption and $\mathrm{CO}_{2}$ emissions

In this paper, different heating systems are considered, such as district heating, also a system with a solid fuel boiler (biomass and wood chips), a gaseous fuel boiler as well as an electric boiler. It is envisaged that further research contains a simulation that will be performed by using a heat pump and solar collectors. The highest $\mathrm{CO}_{2}$ emissions and the primary energy consumption is achieved by applying a heating system with an electrical boiler. The lowest $\mathrm{CO}_{2}$ emissions and the primary energy consumption is when wood biomass heating systems are applied.

\section{CONCLUSION}

As the housing sector is one of the most dominant sectors in energy consumption, this paper aimed to look at a settlement in which identical buildings would be, whose thermal envelope varies for external and attic construction, and the two most commonly used. In this paper, the influence of the type of heating system, variations in the thickness of the thermal insulation sheath from $12 \mathrm{~cm}$ to $22 \mathrm{~cm}$, variations in the thickness of the ceiling insulation from $16 \mathrm{~cm}$ to $30 \mathrm{~cm}$ and construction joinery $\left(\mathrm{U}_{1}=1.3 \mathrm{~W} / \mathrm{m}^{2} \mathrm{~K}\right.$ and $\left.\mathrm{U}_{2}=0.96 \mathrm{~W} / \mathrm{m}^{2} \mathrm{~K}\right)$ on primary energy consumption, $\mathrm{CO}_{2}$ emissions, as well as final energy consumption.

The lowest $\mathrm{CO}_{2}$ emissions and the primary energy consumption is when using wood biomass heating systems, with a ceiling thickness of $25 \mathrm{~cm}$, thermal insulation thickness of $20 \mathrm{~cm}$, and PVC five-chamber windows with low-emission three-layer glass package $4+8+4+8+4$ (unit) with argon (U2 $=0.96 \mathrm{~W} / \mathrm{m}^{2} \mathrm{~K}$ ).

The highest $\mathrm{CO} 2$ emissions and the primary energy consumption is when applying a heating system to electricity.

Acknowledgement: This research was financially supported by the Ministry of Education, Science and Technological Development of the Republic of Serbia, according to contract No. 451-03-9/2021-14/200148. 


\section{REFERENCES}

1. Green Paper, A 2030 Framework for Climate and Energy Policies, COM, 2013, p. 169. http://ec.europa.eu/energy/ consultations/20130702_greenpaper_2030en.htm_European_Commission, 2014. Taking stock of the Europe 2020 strategy for smart sustainable and inclusive growth, Brussels, 19/3/2014.

2. Priručnik za energetsku sertifikaciju zgrada

3. Šumarac D., Todorović M., Đurović-Petrović M., Trišović N. (2010): Energy Efficiency of Residential Buildings in Serbia, Thermal Science, Vol. 14, Suppl. pp. S97-S113.

4. The World Bank: „National Building Energy Efficiency Study for Serbia - Market

5. Assessment Report“, 2012. EconolerDanny S. Parker, E. Mills, Leo I. Rainer," Norm Bourassa and Greg Homan. "Accuracy of the home energy saver energy calculation methodology."

6. Proceedings of the 2012 ACEEE Summer Study on Energy Efficiency in Buildings, American Council for an Energy Efficient Economy (2012)

7. R. Azari, N. Abbasabadi, „Embodied energy of buildings: a review of data, methods, challenges, and research trends“, Energy Build., 168 (2018), pp. 225-235

8. Delia D'Agostino, Danny Parker, Paco Melià, "Environmental and economic implications of energy efficiency in new residential buildings: A multi-criteria selection approach", Energy Strategy Reviews, Vol. 26, 2019

9. Global Alliance for Buildings and Construction, 2018 Global Status Report

10. D. D'Agostino, B. Cuniberti, P. Bertoldi, "Energy consumption and efficiency technology measures in European non-residential buildings European”, Energy Build., 153 (2017), pp. 72-86

11. ŽIVKOVIĆ, Branislav; NOVOSELEC, Atila. Kriterijumi za izračunavanje broja stepen dana. KGH Klimatizacija, grejanje, hlađenje, [S.1.], v. 27, n. 4, p. 45-48, nov. 2016. ISSN 2560-340X.

12. I. Sartori, A.G. Hestnes "Energy use in the life cycle of conventional and low-energy buildings: a review article”, Energy Build., 39 (3) (2007), pp. 249-257

13. A. Koezjakova, D. Urge-Vorsatz, W. Crijns-Graus, M. van den Broeka, ,The relationship between operational energy demand and embodied energy in Dutch residential buildings“, Energy Build. (165) (2018), pp. 233-245

14. Catarina Thormark" A low energy building in a life cycle - its embodied energy, energy need for operation and recycling potential", Build. Environ., 37 (2002), pp. 429-435

\section{UTICAJ ENERGETSKE EFIKASNOSTI MODERNOG STAMBENOG NASELJA NA ŽIVOTNU SREDINU}

Energetska efikasnost u zgradarstvu je prepoznata kao jedan od prioriteta strategije Energetske Unije [1]. Poboljšanje energetske efikasnosti objekata bi trebalo da smanji emisiju gasova staklene bašte (GHG) $i$ nezavisnost od uvoza energije, kao i da utiče na socijalno-ekonomske faktore društva kako Evropske Unije, tako i Srbije. Građevinski sektor sa potrošnjom od oko 40\% primarne energije i 36\% emisijom gasova staklene bašte je jedan od najvećih potrošača u Evropi [2]. Potrošnja energije u stambenom sektoru u Srbiji ima značajan udeo u ukupnoj potrošnji energije od 48\%, od čega se 65\% odnosi na potrošnju energije $u$ individualnim stambenim objektima. $U$ ovom radu analizira se uticaj konstrukcije omotača zgrade i primenjeni sistem grejanja na emisiju ugljendioksida $i$ utrošenu primarnu energiju se procenjuje metodom stepen dana, sagledavajući naselje od 50 istovetnih objekata. Iako pomenutu specifičnu graničnu potrošnju energije određuje nacionalno zakonodavstvo, ovaj rad se bavi analizom uticaja kontrukcije objekata i primenjenih termodinamičkih sistema na troškove i koristi daljim smanjenjem specifične potrošnje do nivoa ispod propisanih vrednosti.

Ključne reči: energetska efikasnost, emisija ugljendioksida, stambeni objekti. 